\title{
Inoperábilis periauricularis daganat sikeres sugárkezelése
}

\author{
Furka Andrea dr. - Szabó Imre dr. - Hevesi Erika dr. \\ Adamecz Zsolt dr. - Pintye Éva dr.
}

Debreceni Egyetem, Klinikai Központ, Onkológiai Intézet, Sugárterápia Nem Önálló Tanszék, Debrecen

\begin{abstract}
A planocellularis bőrdaganatok onkológiai ellátásában a mútét az elsődlegesen választandó modalitás. Rl-reszekció és nyirokcsomó-pozitivitás esetén adjuváns sugárterápia szükséges. Inoperábilis esetekben palliatív céllal ionizáló sugárzás alkalmazható. A szerzők egy 87 éves diabeteses beteg $T_{4} \mathrm{~N}_{1} \mathrm{M}_{0}$ stádiumú periauricularisan elhelyezkedő, nagy kiterjedésű, destruáló daganatának sikeres 3D konformális adaptív külső sugárkezelését kívánják bemutatni, amely során komplett remisszió következett be annak ellenére, hogy palliatívnak indult a kezelés. Orv. Hetil., 2015, 156(40), $1625-1627$.
\end{abstract}

Kulcsszavak: palliatív sugárterápia, laphámrák, periauricularis

\section{Successful treatment of an inoperable periauricular planocellular carcinoma \\ Case report}

Surgery has been considered the first choice of treatment in planocellular skin cancers. However, adjuvant radiotherapy is often required in $\mathrm{Rl}$ resection or in lymph node positivity. Inoperable cases are also treated with ionizing radiation with palliative purpose. The authors present a case report of a successful treatment of an 87-year-old diabetic patient with a T4NIM0 stage periauricular destructive tumour treated with 3D conformal adaptive radiotherapy. Complete remission occurred although the initial treatment aim was only palliation.

Keywords: palliative therapy, squamous cell carcinoma, periauricular

Furka, A., Szabó, I., Hevesi, E., Adamecz, Zs., Pintye, É. [Successful treatment of an inoperable periauricular planocellular carcinoma. Case report]. Orv. Hetil., 2015, 156(40), 1625-1627.

(Beérkezett: 2015. július 9.; elfogadva: 2015. július 30.)

Az inoperábilis planocellularis bőrdaganatok onkológiai ellátásában palliatív céllal ionizáló sugárzás alkalmazható.

\section{Esetismertetés}

A 87 éves, számos kísérő betegséggel rendelkező diabeteses nőbetegnél közel 2 hónapja fennálló, a jobb fül caudalis része körül kifekélyesedő és váladékozó seb miatt kétszer kimetszés történt. Bár a szövettan malignitást nem igazolt, a konvencionális sebkötözés mellett a seb nem gyógyult, destruálta a környező szöveteket és purulenssé vállt (l.a) és b) ábra). Újabb mintavétel történt, amely planocellularis carcinomát igazolt. Ekkorra már a fülkagyló dorsalis részét, a processus mastoideust is infiltráló daganat sebészeti szempontból inoperábilissá vált. A nyaki lágyrész-ultrahangvizsgálat azonos oldali nyirokcsomóáttétet vetett fel.

Egyetlen palliatív megoldásként külső sugárkezelés mellett döntöttünk $[1,2,3,4,5,6]$. CT-szimulációt követóen 3D konformális sugárterápiát terveztünk, Orfitmaszkos fejrögzítót alkalmazva. Célterületnek a daganatot 1 centiméteres biztonsági zónával (amely magába foglalta a gyulladásos margót és az esetleges mikroszkopikus tumorterjedést is), valamint az azonos oldali nyaki nyirokcsomó-láncolatot vettük. Lineáris akcelerátorral 50 Gy palliatív gócdózist terveztünk, napi 2 Gy-s frakciódózisokkal a hét minden munkanapján, hétvégén szünettel, $6 \mathrm{MV}$ fotonenergiát alkalmazva, majd ezt követően 

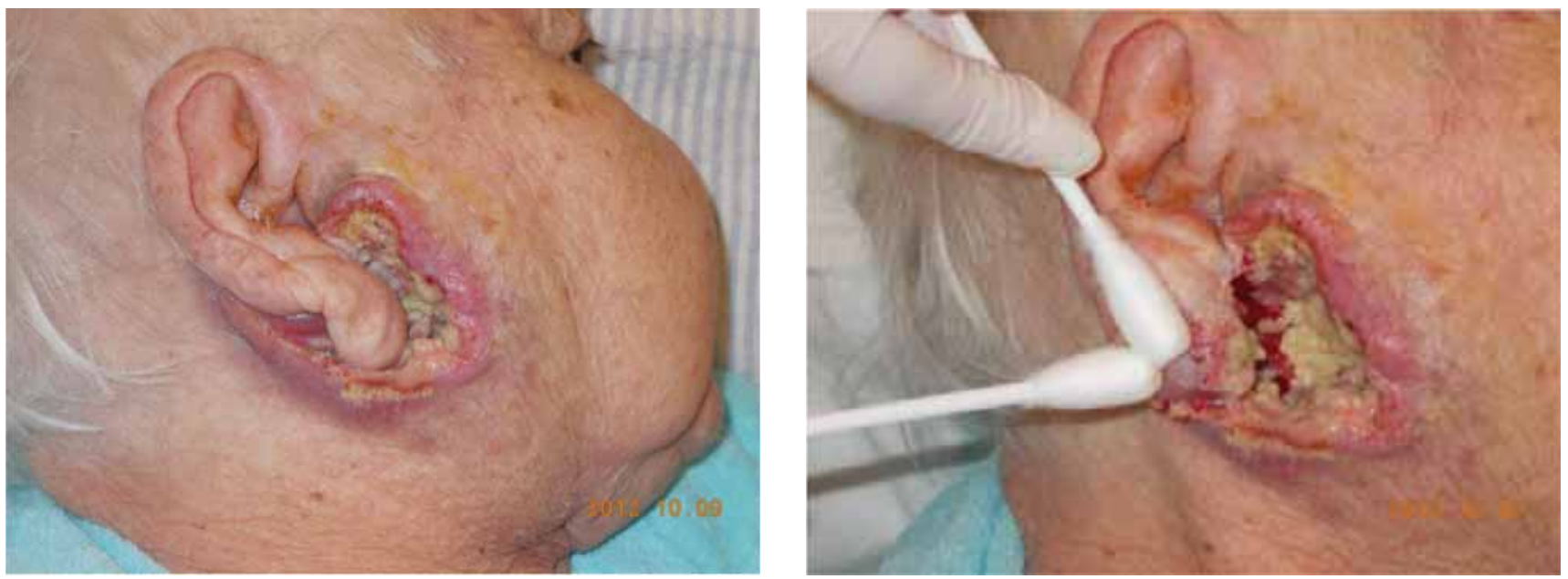

| Jobb fül caudalis része körül elhelyezkedő planocellularis carcinoma képei
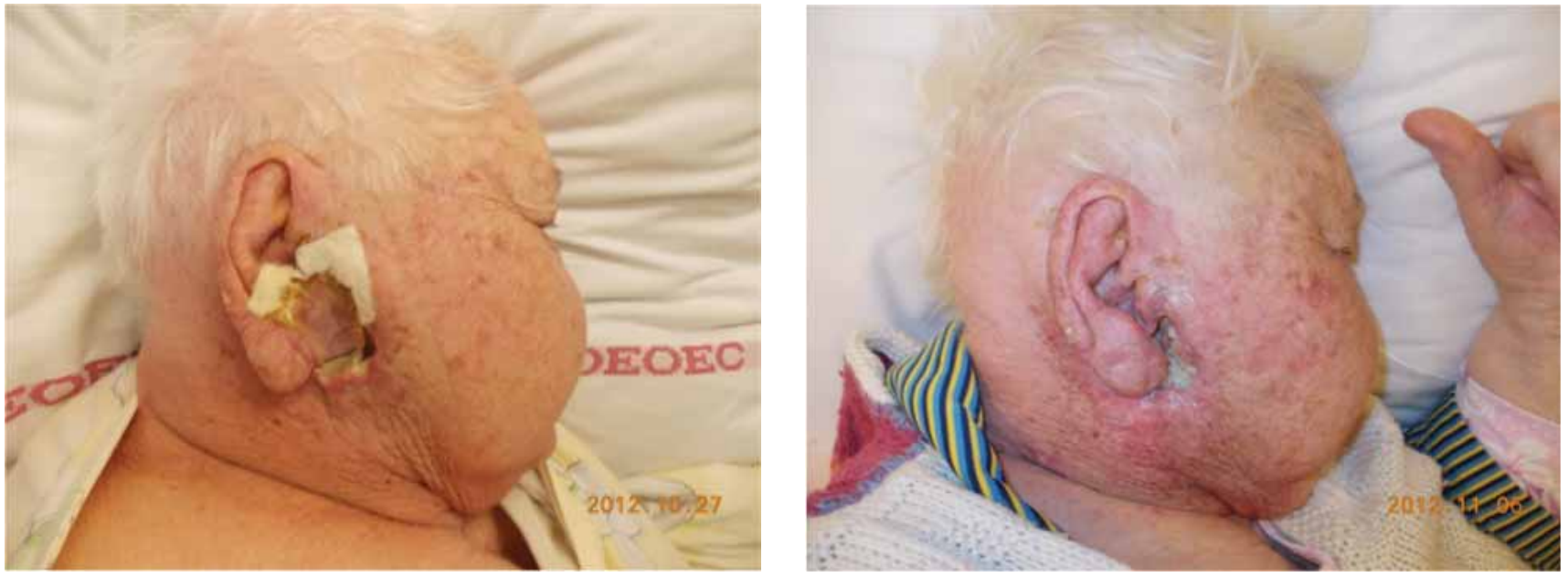

2. ábra

A sugárkezelés negyedik hetében (jobb oldali ábra) jelentős méretbeli csökkenés volt megfigyelhető (a harmadik heti állapothoz képest is, bal oldali ábra), amihez gradus I. radiodermatitis társult

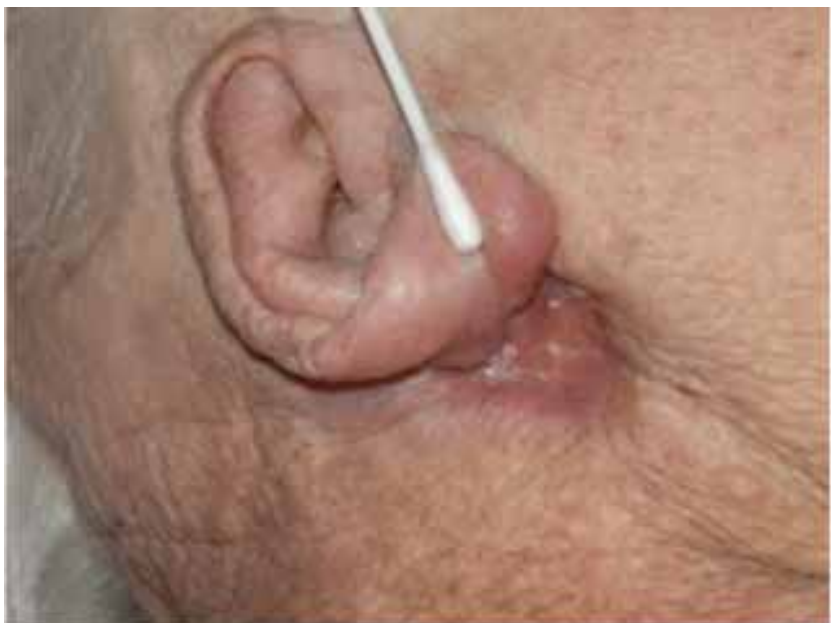

3. ábra | A féléves kontroll során látható hegszövet

16 Gy-t napi 2 Gy-s frakciókkal a tumorágyra szúkítve. A nagy célterület kezelését 3 mezőből végeztük multileaf kollimátort és motorikus éket használva. A szúkítésnél a komformalitás megvalósításához elegendő volt két irreguláris multileaf kollimátor, motorikus ékkel módosított mező alkalmazása, amelyek szintén $6 \mathrm{MV}$ fotonnyalábok voltak. A precíz fektetést, a beteg pozícióját EPID-del (Electronic Portal Imaging Device) készített felvétellel ellenőriztük a kezelés első hetében naponta, majd heti egy alkalommal. A CT-szimulátorból származó képszeletekből a tervezőrendszer által rekonstruált és onnan az EPID-be átküldött BEV (Beam's Eye View) képet és a 6 MV-os fotonnyalábbal készített szummációs iView-képet összehasonlítottuk a mezőhatárok és az anatómiai képletek kontúrozásával és egymásra illesztésével.

A kezelés kezdetén 10 napig $4 \times 300$ mg clindamycint alkalmaztunk per os, valamint naponkénti kötéscserék történtek ezüsttartalmú alginátos intelligens kötszerrel, szükség esetén necrectomiával. A purulens sebváladék feltisztulása után, a seb demarkálódását követően cinkhialuronát tartalmú cseppet alkalmaztunk, valamint a kezelés során fellépő radiodermatitisre lokális hütés (többszöri jegelés rövid időszakokra) mellett nátriumhialuronát és ezüst-szulfadiazin-tartalmú krémet alkal- 
maztunk, szükség esetén 2-3×600 mg ibuprofennel per os kiegészítve.

A kezelés ideje alatt a beteg diabetese végig kontrollált volt, septikaemia nem lépett fel, a beteg mindvégig láztalan volt. A leadott sugárdózis a kezelés alatt megváltozott, az eredeti tervet a tünetekhez adaptáltan módosítottuk. 20 Gy gócdózis leadása után drámai változás lépett fel: a váladékozás mennyisége jelentősen csökkent, a folyamat demarkálódott, ugyanakkor a daganat mérete is csökkent a kezdeti $70 \times 40 \mathrm{~mm}$-ről $55 \times 25 \mathrm{~mm}$-re (a legnagyobb átmérőket figyelembe véve). A harmadiknegyedik héten a nyak bőrén radiodermatitis kezdődött (2. a) és b) ábra), amelyet lokálisan hütöttünk és külsőleg kezeltünk hialuronsavat tartalmazó géllel. Végül a nagy céltérfogat 46 Gy-t kapott, majd a regresszióra való tekintettel újabb lokalizációs CT-t és új tervet készítettünk a szúkítésre, amire a tervezett 16 Gy-ből 10 Gy-t adtunk le. A tumorágy így összesen 54 Gy gócdózist kapott. Az azonos oldali nyaki régióban jelentkező fájdalmas radiodermatitis miatt (amelynek kialakulásában az elhízott beteg alkati tulajdonságai, így többek között a sugármezőben összefekvő bőrráncok játszottak szerepet) a beteg kérte a kezelés megszakítását. A sebet naponta kötöztük, többek között azért is, mert a sugárkezelés előtt a kötés eltávolítása szükséges, hogy a kötszer ne eredményezzen bolushatást és ne növelje a bör terhelését. A 3 hónapos kontrollnál $5 \mathrm{~mm}$-es laesio volt megfigyelhető, igen minimális savós váladékozással, és a radiodermatitis is gyógyult. A féléves kontroll során csak egy igen kicsiny hegszövet visszamaradása volt megfigyelhető (3. ábra). A beteg korára és társbetegségeire való tekintettel mưtét nem jött szóba. A kezelést követően egy év múlva a beteg szívelégtelenségben hunyt el. Recidíváról, nyaki nyirokcsomó- vagy távoli áttétről nem volt tudomásunk, azaz teljes remisszióról beszélhetünk.

\section{Megbeszélés}

A palliatív indikáció ellenére a kezelés kuratívnak bizonyult. Így a korai (átmeneti) mellékhatások mellett igen jó életminőséget sikerült biztosítani a beteg és családja számára. Esetünk arra hívja fel a figyelmet, hogy inkurábilisnak véleményezett planocellularis bőrdaganatok esetében is mérlegelni kell a sugárterápia lehetőségét. Időskorban is biztonsággal és sikerrel végezhető a sugárkezelés a számos kísérő betegség ellenére is. Jelen esetben mindvégig sikerült a diabetest kontrollálni és a szeptikus állapotot elkerülni. Az adaptív sugárterápia alkalmazásával a mellékhatások csökkenthetők és a kezelé- sek individuálisabbá tehetők. Rendkívül fontos a teammunka, a sugárterapeuta, a sebész és a bőrgyógyász, valamint az orvos fizikus minimum hetenkénti konzultációja és az asszisztensek pontos, lelkiismeretes munkája. Mindezen túl igen fontosnak tartjuk a betegek szoros obszervációját, és a panaszok mérlegelésével, szükség esetén új terv elkészítésével a személyre szabott sugárkezelést biztosítani, amivel akár teljes gyógyulás is elérhető.

Anyagai támogatás: A közlemény megírása anyagi támogatásban nem részesült.

Szerzői munkamegosztás: F. A. sebész-sugárterapeuta: A kézirat szerkesztése, a beteg kezelésének koordinálása. Sz. I. bőrgyógyász-sugárterapeuta, H. E.: Sebkötözés. A. Zs. sugárterápiás konzulens, P. É. klinikai sugárfizikus: A sugárterápiás terv elkészítése, a kézirat szerkesztése. A cikk végleges változatát valamennyi szerző elolvasta és elfogadta.

Érdekeltségek: A szerzőknek a jelen tanulmányhoz kapcsolódó anyagi érdekeltségeik nincsenek.

\section{Irodalom}

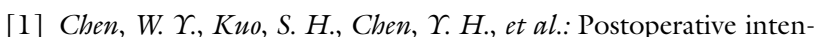
sity-modulated radiotherapy for squamous cell carcinoma of the external auditory canal and middle ear: treatment outcomes, marginal misses, and perspective on target delineation. Int. J. Radiat. Oncol. Biol. Phys., 2012, 82(4), 1485-1493.

[2] Pfister, D. G., Spencer, S., Brizel, D. M., et al.: Head and neck cancers, Version 1.2015. J. Natl. Compr. Canc. Netw., 2015, 13(7), 847-856.

[3] Manyam, B. V., Gastman, B., Zhang, A. Y., et al.: Inferior outcomes in immunosuppressed patients with high-risk cutaneous squamous cell carcinoma of the head and neck treated with surgery and radiation therapy. J. Am. Acad. Dermatol., 2015, 73(2), 221-227.

[4] Porceddu, S. V.: Prognostic factors and the role of adjuvant radiation therapy in non-melanoma skin cancer of the head and neck. Am. Soc. Clin. Oncol. Educ. Book, 2015, 35, e513-e518.

[5] Mydlarz, W. K., Weber, R. S., Kupferman, M. E.: Cutaneous malignancy of the head and neck. Surg. Oncol. Clin. N. Am., 2015, $24(3), 593-613$.

[6] Samstein, R. M., Ho, A. L., Lee, N. Ү., et al.: Locally advanced and unresectable cutaneous squamous cell carcinoma: outcomes of concurrent cetuximab and radiotherapy. J. Skin Cancer, $2014,2014,284582$

(Furka Andrea dr., Debrecen, Hatvani I. u. 13/B, 4032 e-mail: furka.andrea@med.unideb.hu) 